International Journal of Current Advanced Research

ISSN: O: 2319-6475, ISSN: P: 2319 - 6505, Impact Factor: SJIF: 5.995

Available Online at www.journalijcar.org

Volume 6; Issue 3; March 2017; Page No. 2926-2928

DOI: http://dx.doi.org/10.24327/ijcar.2017.2928.0144

Review Article

\title{
STATUS OF PARTIAL EDENTULISM IN THE RURAL AREA OF THIRUVALLUR
}

\author{
Hena Mariam Fathima., Dhanraj and Marian Anand
}

Saveetha Dental College, Poonamallee High Road, Chennai- 600077

\section{A R T I C L E I N F O}

\section{Article History:}

Received $12^{\text {th }}$ December, 2016

Received in revised form $2^{\text {nd }}$ January, 2017

Accepted $25^{\text {th }}$ February, 2017

Published online $28^{\text {th }}$ March, 2017

\section{Key words:}

Causes, Partial Edentulism,

Status, Thiruvallur

\begin{abstract}
A B S T R A C T
Aim: To determine the status of partial edentulism in the rural area of Thiruvallur

Materials and Methods: A simple random sampling was carried out among 250 individuals in the rural district of Thiruvallur. A self assessed questionnaire comprising of 12 questions was given and a clinical examination was conducted. Out of the 250 individuals, 102 were partially edentulous. The information was gathered based on various demographics.
\end{abstract}

Background: Partial edentulousness is a dental arch in which one or more but not all natural teeth are missing. Generally, it occurs by caries, periodontal problems, traumatic injuries and cystic lesions. Partial edentulism leads to several drawbacks to the subjects including clinical challenges and lifestyle compromises. Clinically, partial edentulism results in drifting and tilting of adjacent teeth, supra eruption of opposing teeth, altered speech, changes in facial appearance and tempero-mandibular disorders.

Reason: Studies related to partial edentulism are scarce especially in the rural parts of South India, even though it affects many. It affects the patient's life drastically and knowing the status of partial edentulism in that area can help combat it.

Result: The prevalence of partial edentulism in the study population form rural Thiruvallur area is relatively high.

Copyright@2017 Hena Mariam Fathima., Dhanraj and Marian Anand. This is an open access article distributed under the Creative Commons Attribution License, which permits unrestricted use, distribution, and reproduction in any medium, provided the original work is properly cited.

\section{INTRODUCTION}

One of the most important oral health indicators is the ability to retain more number of teeth throughout life. Edentulism or complete tooth loss is prevalent worldwide among older people. Earlier studies have shown that edentulism affects the health and the overall quality of life of the elderly ${ }^{1}$. Earlier studies have shown an association between sociodemographic factors, lifestyles, and tooth loss ${ }^{1-3}$ Tooth loss has been reported to be mainly due to dental caries and periodontal disease ${ }^{4,5,6}$ The complex interaction between dental diseases, the tendency to use dental care, dental attitude, and affordability of non-extraction treatment have been related to the incidence of tooth loss. ${ }^{7}$ Women with a low education level, low economic status, and those who did not brush their teeth showed a higher average of missing teeth. ${ }^{8}$ Age, gender, low family income, and rural domicile have been associated with edentulism. ${ }^{9}$ Tooth loss impairs the quality of life, and also it affects the well-being of the person. Missing teeth can interfere with chewing ability, diction, and esthetics. Low self-esteem related to tooth loss can hinder an individual's ability to socialize, hamper the performance of

*Corresponding author: Hena Mariam Fathima

Saveetha Dental College, Poonamallee High Road, Chennai600077 work and daily activities, and lead to absence from work. ${ }^{10}$ Information about the frequency of tooth loss and its risk factors in developing countries is sparse. Relatively very few studies have been conducted to know the risk indicators related with tooth loss among Indian adults. ${ }^{11,12}$

\section{MATERIALS AND METHODS}

A simple random sampling was carriedout among 250 patients. A self assessed questionnaire comprisingof 12 questions was given to the patients and clinical examination was done for the partially edentulous patients. Out of the 250 patients, 102 were partially edentulous. The information gathered was based on various demographics (age, sex, income, reasons for not restoring). Data extraction was done from the partially edentulous patients and processed.

\section{RESULTS AND DISCUSSION}

Loss of teeth reflects a major public health problem in many countries. ${ }^{13}$ Edentulism has a significant impact on health and the overall quality of life. ${ }^{14}$ Studies on self-perception have shown that tooth loss is associated with functional, psychological, and social impacts on individuals. ${ }^{1,15-17}$. When patients had missing teeth in the anterior region along with missing teeth in the posterior region, their primary reason for replacement was aesthetics. ${ }^{18}$ 


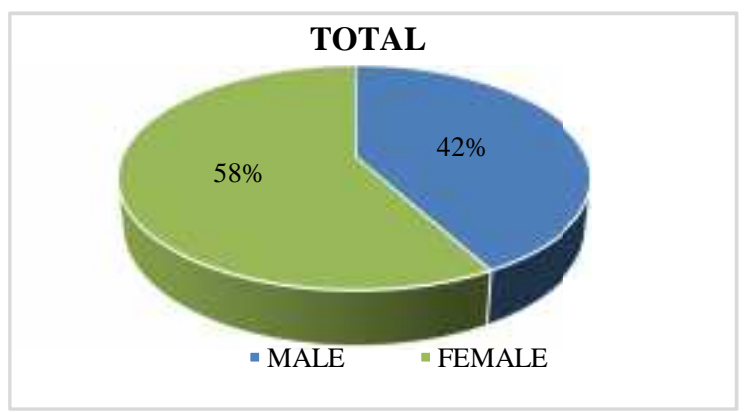

Fig 1 Sex of the Patient

\section{\% OF PEOPLE PARTIALLY EDENTULOUS}

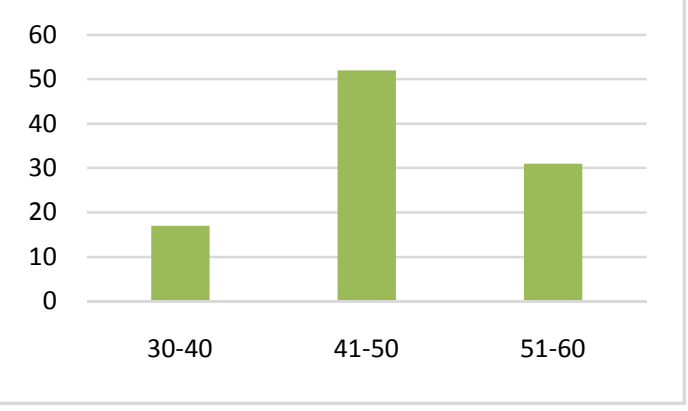

Fig 2 Age Group

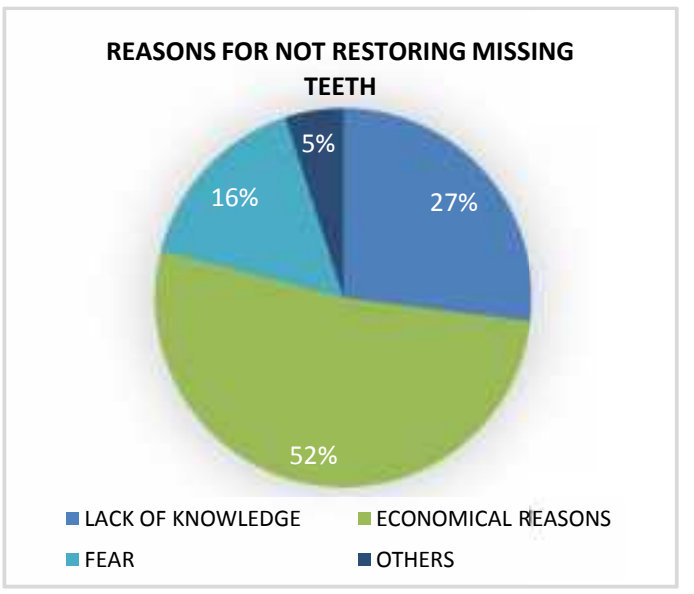

Fig 3 Reasons for Not Restoring

Loss of teeth reflects a major public health problem in many countries. ${ }^{13}$ Edentulism has a significant impact on health and the overall quality of life. ${ }^{14}$ Studies on self-perception have shown that tooth loss is associated with functional, psychological, and social impacts on individuals. ${ }^{15-17}$. When patients had missing teeth in the anterior region along with missing teeth in the posterior region, their primary reason for replacement was aesthetics. ${ }^{18}$

Among the population examined $42 \%$ of them were males and $58 \%$ of them were females. The present study shows an association between gender and edentulism. It was observed that a majority of the study population comprised partially edentulous female patientsThe age group of 30-40 years had $17 \%$ of people that were partially edentulous, the age group of $41-50$ had $52 \%$, the age group of 51-60 had 31\%. It can be seen that the most number of partially edentulous patients lie in the 41-50 age group. This could be because of periodontal problems, dental caries, weakening of the alveolar bone among others. From the survey, it was found that $52 \%$ did not restore the missing teeth due to economical reasons, $27 \%$ due to lack of knowledge and $16 \%$ due to fear. Since the economical status of the majority was quite low, they were unable to afford treatment. The prevalence of partial edentulism in the study population form rural Thiruvallur area is relatively high. The awareness about rehabilitation of partial edentulous state is also inadequate.

\section{CONCLUSION}

Hence, more awareness and treatment programmes need to be initiated to address this concern. They require communitybased oral health programs to increase the awareness and reduce the risk for tooth loss. There is a definitive need for a step-by-step approach in eradicating the cause all over the country with special focus on people who suffer from socioeconomic and geographical disadvantage.

\section{References}

1. Shamdol Z, Ismail N, Hamzah N, Ismail A. Prevalence and associated factors of edentulism among elderly Muslims in Kota Bharu, Kelantan, Malaysia. JIMA 2008;40:143-8. 2. Esan TA, Olusile AO, Akeredolu PA, Esan AO. Sociodemographic factors and edentulism: The Nigerian experience. BMC Oral Health 2004;4(1):3.

2. Cunha-Cruz J, Hujoel PP, Nadanovsky P. Secular trends in socio-economic disparities in edentulism: USA, 19722001. J Dent Res 2007;86(2):131-6.

3. Irene A Kida, Anne N Astrøm, Gunhild V Strand and Joyce R Masalu. Clinical and socio-behavioral correlates of tooth loss: a study of older adults in Tanzania. BMC Oral Health; 2006; 6:5

4. K .O. Savage and P. O. Ayanbadejo. Pattern of Exodontia Treatment Need Adults Attending The Lagos University Teaching Hospital Dental Clinic. Nig. Ot J. Hosp. Med. April-June.2005; Vol. 15(2)

5. B. O. Sanya, p. M. Ng'ang'a and R. N. Ng'ang'a. Causes and pattern of missing permanent teeth among kenyans. East African Medical Journal; June 2004; Vol. 81 No. 6

6. Gilbert GH, Miller MK, Duncan RP, Ringelberg ML, Dolan TA, Foerster U. Tooth-specific and person-level predictors of 24-month tooth loss among older adults. Community Dent Oral Epidemiol 1999;27(5):372-85.

7. Lin HC, Corbet EF, Lo EC, Zhang HG. Tooth loss, occluding pairs, and prosthetic status of Chinese adults. $J$ Dent Res 2001;80(5):1491-5.

8. Medina-Solís CE, Pérez-Núñez R, Maupomé G, Casanova-Rosado JF. Edentulism among Mexican adults aged 35 years and older and associated factors. Am J Public Health 2006;96(9):1578-81.

9. Batista MJ, Rihs LB, Sousa Mda L. Risk indicators for tooth loss in adult workers. Braz Oral Res 2012;26(5):390-6.

10.Jaleel BF, Nagarajappa R, Mohapatra AK, Ramesh G. Risk indicators associated with tooth loss among Indian adults. Oral Health Dent Manag 2014;13(2):170-8.

11.D'Souza KM, Aras M. Association between sociodemographic variables and partial edentulism in the Goan population: An epidemiological study in India. Indian J Dent Res 2014;25(4):434-8.

12. Teófilo LT, Leles CR. Patients' self-perceived impacts and prosthodontic needs at the time and after tooth loss. Braz Dent J 2007;18(2):91-6. 
13. Shimazaki Y, Soh I, Saito T, Yamashita Y, Koga T, Miyazaki $\mathrm{H}$, et al. Influence of dentition status on physical disability, mental impairment, and mortality in institutionalized elderly people. $J$ Dent Res 2001;80(1):340-5.

14. Johnson NW, Glick M, Mbuguye TN. (A2) Oral health and general health. Adv Dent Res 2006;19(1):118-21.

15. Hamasha AA, Sasa I, Al-Qudah M. Risk indicators associated with tooth loss in Jordanian adults. Community Dent Oral Epidemiol 2000;28(1):67-72.
16. Gilbert GH, Duncan RP, Crandall LA, Heft MW, Ringelberg ML. Attitudinal and behavioral characteristics of older Floridians with tooth loss. Community Dent Oral Epidemiol 1993;21(6):384-9.

17. Elias AC, Sheiham A. The relationship between satisfaction with mouth and number and position of teeth. J Oral Rehabil 1998;25:649-61.

\section{How to cite this article:}

Hena Mariam Fathima et al (2017) ' Status Of Partial Edentulism In The Rural Area Of Thiruvallur', International Journal of

Current Advanced Research, 06(03), pp. 2926-2928.

DOI: http://dx.doi.org/10.24327/ijcar.2017.2928.0144 